\title{
Antihyperglycemic studies with boiled and non-boiled Vigna mungo seeds
}

\author{
Shakila Jahan Mou, Md Rasel Ahmed, Shahnaz Rahman, ABM Anwarul Bashar, Erena Islam, Mohammed \\ Rahmatullah* \\ University of Development Alternative, Dhaka, Bangladesh.
}

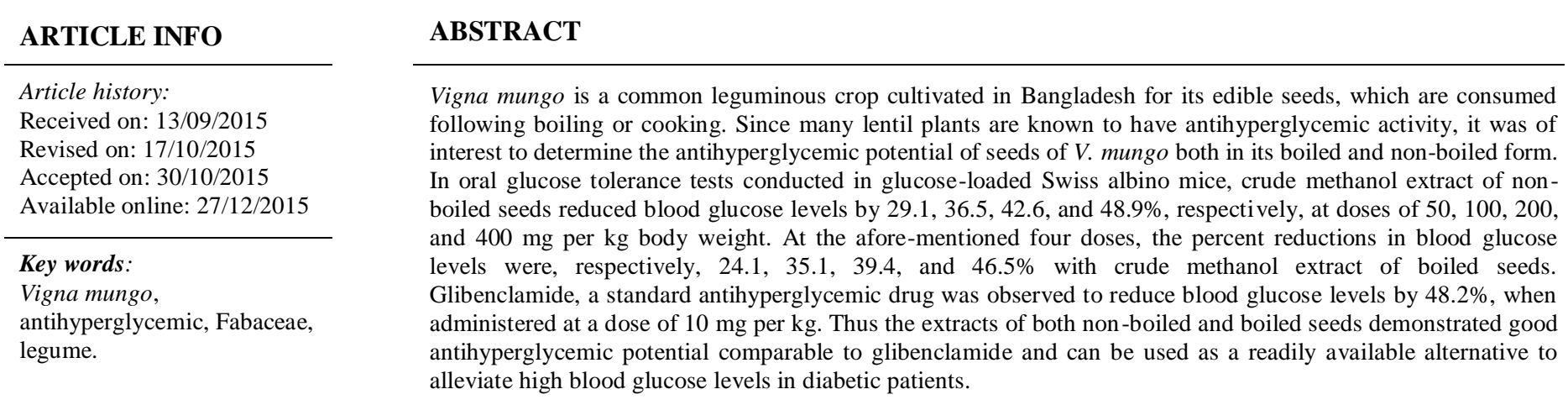

\section{INTRODUCTION}

Vigna mungo (L.) Hepper is a legume crop cultivated in Bangladesh for its edible seeds, which are consumed following boiling in water and taken as lentil soup, or consumed in the cooked form with other vegetables, fish or meat. The plant belongs to the Fabaceae family and is known in English as black gram, black lentil or mungo bean and in Bangladesh as mashkalai dal. Seeds of the plant have been reported to have considerable hypolipidemic action (Indira and Kurup, 2003). Various solvent extracts of the seeds have been shown to demonstrate immunostimulatory activity (Dhumal et al., 2013). In our ongoing program for antihyperglycemic and analgesic plants of Bangladesh (Morshed et al., 2010; Rahmatullah et al., 2010; Ahmed et al., 2011; Shahreen et al., 2012; Haque et al., 2013; Haque et al., 2014; Rahmatullah et al., 2013a,b; Ghosh et al., 2014; Hossain et al., 2014; Jahan et al., 2014; Rahman et al., 2014; Tazin et al., 2014), it was of interest to conduct such antihyperglycemic studies on $V$. mungo seeds. Moreover, since

* Corresponding Author

Mohammed Rahmatullah, University of Development Alternative, Dhaka,Bangladesh.Email: rahmatm@uoda.edu.bd the seeds are consumed in the boiled form, it was of further interest to evaluate the comparative antihyperglycemic potential of both non-boiled and boiled seeds. Antihyperglycemic activity evaluation was conducted through oral glucose tolerance tests (OGTT) in glucose-loaded Swiss albino mice.

\section{MATERIALS AND METHODS}

\section{Plant material collection}

Seeds of V. mungo were collected during May 2015 from a local market in Dhaka city, Bangladesh.

\section{Preparation of methanolic extract of non-boiled and boiled seeds}

For preparation of extract of non-boiled seeds, seeds were de-husked, thoroughly dried and powdered and $150 \mathrm{~g}$ of powdered seeds were extracted with methanol (w:v ratio of 1:5), final weight of the extract $(6.686 \mathrm{~g})$. For preparation of extract of boiled seeds, de-husked and dried seeds were first steamed for 15 minutes over boiling water, then dried and powdered followed by extraction with methanol (w:v ratio of1:5), final weight of the extract (5.069g). 


\section{Chemicals and Drugs}

Glibenclamide and glucose were obtained from Square Pharmaceuticals Ltd., Bangladesh. All other chemicals were of analytical grade.

\section{Animals}

Swiss albino mice, which weighed between $12-16 \mathrm{~g}$ were used in the present study. The animals were obtained from International Centre for Diarrhoeal Disease Research, Bangladesh (ICDDR, B). The animals were acclimatized for three days prior to actual experiments. The study was conducted following approval by the Institutional Animal Ethical Committee of University of Development Alternative, Dhaka, Bangladesh.

\section{Oral glucose tolerance tests for evaluation of antihyperglycemic activity}

Oral glucose tolerance tests (OGTT) were carried out as per the procedure previously described by Joy and Kuttan (1999) with minor modifications. Briefly, fasted mice were grouped into ten groups of five mice each. The various groups received different treatments like Group 1 received vehicle (1\% Tween 80 in water, $10 \mathrm{ml} / \mathrm{kg}$ body weight) and served as control, Group 2 received standard drug (glibenclamide, $10 \mathrm{mg} / \mathrm{kg}$ body weight). Groups 3-6 received methanolic non-boiled seed extract (MEVM) at doses of 50,100, 200 and $400 \mathrm{mg}$ per kg body weight. Groups 7-10 received boiled seed extract (MEVM) at doses of 50, 100, 200 and $400 \mathrm{mg}$ per kg body weight. All substances were orally administered. Following a period of one hour, all mice were orally administered $2 \mathrm{~g}$ glucose $/ \mathrm{kg}$ of body weight. Blood samples were collected 120 minutes after the glucose administration through puncturing heart. Blood glucose levels were measured by glucose oxidase method (Venkatesh et al., 2004). The percent lowering of blood glucose levels were calculated according to the formula described below.

Percent lowering of blood glucose level $=\left(1-\mathrm{W}_{\mathrm{e}} / \mathrm{W}_{\mathrm{c}}\right)$ X 100, where $\mathrm{W}_{\mathrm{e}}$ and $\mathrm{W}_{\mathrm{c}}$ represents the blood glucose concentration in glibenclamide or MEVM administered mice (Groups 2-10), and control mice (Group 1), respectively.

\section{Statistical analysis}

Experimental values are expressed as mean \pm SEM. Independent Sample t-test was carried out for statistical comparison. Statistical significance was considered to be indicated by a p value $<0.05$ in all cases (Hossain et al., 2014).

\section{RESULTS AND DISCUSSION}

In oral glucose tolerance tests conducted with glucoseloaded Swiss albino mice, crude methanol extract of non-boiled seeds reduced blood glucose levels by $29.1,36.5,42.6$, and $48.9 \%$, respectively, at doses of 50,100, 200, and $400 \mathrm{mg}$ per kg body weight. At the afore-mentioned four doses, the percent reductions in blood glucose levels were, respectively, 24.1, 35.1, 39.4, and $46.5 \%$ with crude methanol extract of boiled seeds.
Glibenclamide, a standard antihyperglycemic drug was observed to reduce blood glucose levels by $48.2 \%$, when administered at a dose of $10 \mathrm{mg}$ per $\mathrm{kg}$. The results are shown in Table 1.

Table 1: Effect of crude methanol extract of non-boiled and boiled $V$. mungo seeds (MEVM) on blood glucose level in hyperglycemic mice following 120 minutes of glucose loading.

\begin{tabular}{lccc}
\hline \multicolumn{1}{c}{ Treatment } & $\begin{array}{c}\text { Dose }(\mathbf{m g} / \mathbf{k g} \\
\text { body weight) }\end{array}$ & $\begin{array}{c}\text { Blood glucose } \\
\text { level }(\mathbf{m m o l} / \mathbf{l})\end{array}$ & $\begin{array}{c}\text { \% lowering of } \\
\text { blood glucose } \\
\text { level }\end{array}$ \\
\hline Control & $10 \mathrm{ml}$ & $5.64 \pm 0.21$ & - \\
Glibenclamide & $10 \mathrm{mg}$ & $2.92 \pm 0.29$ & $48.2^{*}$ \\
(MEVM) non-boiled & $50 \mathrm{mg}$ & $4.00 \pm 0.48$ & $29.1^{*}$ \\
(MEVM) non-boiled & $100 \mathrm{mg}$ & $3.58 \pm 0.45$ & $36.5^{*}$ \\
(MEVM) non-boiled & $200 \mathrm{mg}$ & $3.24 \pm 0.45$ & $42.6^{*}$ \\
(MEVM) non-boiled & $400 \mathrm{mg}$ & $2.88 \pm 0.43$ & $48.9^{*}$ \\
(MEVM) boiled & $50 \mathrm{mg}$ & $4.28 \pm 0.28$ & $24.1^{*}$ \\
(MEVM) boiled & $100 \mathrm{mg}$ & $3.66 \pm 0.32$ & $35.1^{*}$ \\
(MEVM) boiled & $200 \mathrm{mg}$ & $3.42 \pm 0.24$ & $39.4^{*}$ \\
(MEVM) boiled & $400 \mathrm{mg}$ & $3.02 \pm 0.30$ & $46.5^{*}$ \\
\hline
\end{tabular}

All administrations were made orally. Values represented as mean \pm SEM, $(\mathrm{n}=5) ;{ }^{*} P<0.05$; significant compared to hyperglycemic control animals.

The results indicate that MEVM (non-boiled) at the highest dose of $400 \mathrm{mg}$ per $\mathrm{kg}$ was comparable in its blood glucose lowering efficacy to glibenclamide and can be substituted for the drug. MEVM (boiled) at all doses gave lower glucose lowering efficacy than the non-boiled extract, but the effects were only marginally lower. Thus at the highest dose of MEVM (nonboiled), the extract lowered blood glucose levels by $48.9 \%$, while the extract (boiled) at the same dose, lowered blood glucose levels by $46.5 \%$. Taken together, the results suggest that both non-boiled as well as boiled seed extract can be used for lowering blood glucose. Since the seeds of $V$. mugno are readily available and affordable in Bangladesh ( $V$. mungo seeds are the lowest-priced lentil or pulse seed in Bangladesh) and are edible, the seeds can offer a cheaper alternative to diabetic patients for lowering blood glucose.

Legumes have been reported to lower glycemic responses by slowing down the absorption of carbohydrates or inhibiting its digestion. The causative agents behind these actions reportedly include dietary fiber and uronic acid in the legumes (Baer et al., 1998). Since V. mungo is a leguminous crop, the above can explain the observed antihyperglycemic effect of the seeds, which contains high levels of fiber (Khan et al., 2009) and so may have decreased absorption of glucose. This may also explain the somewhat lower glucose lowering efficacy of the seeds following steaming. Steaming may have partially digested some fibers and so enabled more glucose uptake.

Diets rich in legumes have been reported to lower the risk if diabetes and improve glycemic control (Ley et al., 2014). Antioxidants in horse gram (a leguminous crop) have been postulated to reduce the risk of diabetes (Prasad and Singh, 2015). Dietary supplementation with fermented legumes has been shown to modulate hyperglycemia and acetylcholinesterase activities in streptozotocin-induced diabetes (Ademiluyi et al., 2015). Thus $V$. mungo or black gram can also be a potential dietary factor in reducing the risk of diabetes incidences and lowering blood 
glucose. As such, the seeds deserve scientific attention towards identifying the mechanism responsible for the observed antihyperglycemic effect.

\section{CONCLUSION}

The results suggest that methanolic extract of $V$. mungo non-boiled as well as boiled seed extract can be used for lowering of blood glucose.

\section{ACKNOWLEDGEMENTS}

The authors declare that they have no conflicts of interest.

\section{REFERENCES}

Ademiluyi AO, Oboh G, Boligon AA, Athayde ML. Dietary supplementation with fermented legumes modulate hyperglycemia and acetylcholinesterase activities in Streptozotocin-induced diabetes. Pathophysiology, 2015; (in press).

Ahmed F, Rahman S, Ahmed N, Hossain M, Biswas A, Sarkar S, Banna H, Khatun MA, Chowdhury MH, Rahmatullah M. Evaluation of Neolamarckia cadamba (Roxb.) Bosser leaf extract on glucose tolerance in glucose-induced hyhperglycemic mice. Afr J Trad Complement Altern Med, 2011; 8:79-81.

Akter M, Mitu IZ, Proma JJ, Rahman SM, Islam MR, Rahman S, Rahmatullah M. Antihyperglycemic and antinociceptive activity evaluation of methanolic extract of Trichosanthes anguina fruits in Swiss albino mice. Adv Nat Appl Sci, 2014; 8:70-74.

Baer DJ, Rumpler WV, Milles CW, Fahey GC. Dietary fiber decreases the metabolizable energy content and nutrient digestibility of mixed diets fed to Human. J Nutr, 1998; 127:579-586.

Dhumal JS, Yele SU, Ghodekar SN. Evaluation of immunomodulatory activity of Vigna mungo (L) Hepper. J Pharm Phytother, 2013; 1:9-14.

Ghosh D, Mandal I, Rumi JF, Trisha UK, Jannat H, Ahmed M, Rahmatullah M. Effect of Allium sativum leaf extracts on glucose tolerance in glucose-induced hyperglycemic mice. Adv Nat Appl Sci, 2014; 8:66-69.

Haque ME, Rahman S, Rahmatullah M, Jahan R. Evaluation of antihyperglycemic and antinociceptive activity of Xanthium indicum stem extract in Swiss albino mice. BMC Complement Alternat Med, 2013; 13:296-299.

Haque AKMM, Kabir MZ, Rahman S, Rahman MM, Jahan R, Hossan MS, Rahmatullah M. Preliminary phytochemical screening, oral glucose tolerance, analgesic and acute toxicity studies with Dendrocalamus giganteus aerial parts. J Chem Pharmaceut Res, 2014; 6:397-402.

Hossain AI, Faisal M, Rahman S, Jahan R, Rahmatullah M. A preliminary evaluation of antihyperglycemic and analgesic activity of Alternanthera sessilis aerial parts. BMC Complement Alternat Med, 2014; 14:169-173.

Indira M, Kurup PA. Black gram (Vigna mungo)-A hypolipidemic pulse. Nat Prod Radiance, 2003; 2:240-242.
Jahan S, Rahmatullah M. Methanolic extract of aerial parts of Raphanus sativus var. hortensis shows antihyperglycemic and antinociceptive potential. World J Pharm Pharmaceut Sci, 2014; 3:193202.

Joy KL, Kuttan RJ. Anti-diabetic activity of Picrorrhiza kurroa extract. J Ethnopharmacol, 1999; 67:143-148.

Khan S, Khan ML, Bhatty N. Blood glucose responses to conventional leguminous dishes in normal and diabetics. J Animal Plant Sci, 2009; 19:63-66.

Ley SH, Hamdy O, Mohan V, Hu FB. Prevention and management of type 2 diabetes: dietary components and nutritional strategies. Lancet, 2014; 383:1999-2007.

Morshed A, Hossain MH, Shakil S, Nahar K, Rahman S, Ferdausi D, Hossain T, Ahmad I, Chowdhury MH, Rahmatullah M. Evaluation of antinociceptive activity of two Bangladeshi medicinal plants, Kalanchoe pinnata (Lam.) Pers. and Lagerstroemia speciosa (L.) Pers. Adv Nat Appl Sci, 2010; 4:193-197.

Prasad SK, Singh MK. Horse gram- an underutilized nutraceutical pulse crop: a review. J Food Sci Technol, 2015; 52:24892499.

Rahman S, Jahan R, Rahmatullah M. Effect of paddy husk extracts on glucose tolerance in glucose-induced hyperglycemic mice. World J Pharm Pharmaceut Sci, 2014; 3:111-120.

Rahmatullah M, Sultan S, Toma TT, Lucky SS, Chowdhury MH, Haque WM, Annay MEA, Jahan R. Effect of Cuscuta reflexa stem and Calotropis procera leaf extracts on glucose tolerance in glucoseinduced hyperglycemic rats and mice. Afr $\mathrm{J}$ Trad Complement Altern Med, 2010; 7:109-112.

Rahmatullah M, Hosain M, Rahman S, Rahman S, Akter M, Rahman F, Rehana F, Munmun M, Kalpana MA. Antihyperglycaemic and antinociceptive activity evaluation of methanolic extract of whole plant of Amaranthus tricolour L. (Amaranthaceae). Afr J Trad Complement Altern Med, 2013a; 10:408-411.

Rahmatullah M, Hossain M, Mahmud A, Sultana N, Rahman SM, Islam MR, Khatoon MS, Jahan S, Islam F. Antihyperglycemic and antinociceptive activity evaluation of 'khoyer' prepared from boiling the wood of Acacia catechu in water. Afr J Trad Complement Altern Med, $2013 b ; 10: 1-5$

Shahreen S, Banik J, Hafiz A, Rahman S, Zaman AT, Shoyeb MA, Chowdhury MH, Rahmatullah M. Antihyperglycemic activities of leaves of three edible fruit plants (Averrhoa carambola, Ficus hispida and Syzygium samarangense) of Bangladesh. Afr J Trad Complement Altern Med, 2012; 9:287-291.

Tazin TQ, Rumi JF, Rahman S, Al-Nahain A, Jahan R, Rahmatullah M. Oral glucose tolerance and antinociceptive activity evaluation of methanolic extract of Vigna unguiculata ssp. unguiculata beans. World J Pharm Pharmaceut Sci, 2014; 3:28-37.

Venkatesh S, Reddy GD, Reddy YSR, Sathyavathy D, Reddy B. Effect of Helicteres isora root extracts on glucose tolerance in glucoseinduced hyperglycemic rats. Fitoterapia, 2004; 75:364-367.

\section{How to cite this article:}

Mou SJ, Ahmed MR, Rahman S, Anwarul Bashar ABM, Islam E, Rahmatullah M. Antihyperglycemic studies with boiled and nonboiled Vigna mungo seeds. J App Pharm Sci, 2015; 5 (12): 135137. 